\title{
Knowledge, Behavior and Attitudes Concerning STI Prevention among Out-of-School Youth in the Philippines
}

\author{
Yuko Tanaka ${ }^{1, *}$, Cecilia L. Llave ${ }^{2}$, Maria Teresa Reyes Tuliao ${ }^{3}$, Tadashi Yamashita ${ }^{4}$, Hiroya Matsuo ${ }^{5}$ \\ ${ }^{1}$ Department of School Health Sciences, Faculty of Medicine, Tokushima University Graduate School, Japan \\ ${ }^{2}$ University of the Philippines (UP)-College of Medicine (CM), Philippines \\ ${ }^{3}$ City Health Department of Muntinlupa, Philippines \\ ${ }^{4}$ Kobe City College of Nursing, Japan \\ ${ }^{5}$ Graduate School of Health Science, Kobe University, Japan
}

Copyright $\odot 2017$ by authors, all rights reserved. Authors agree that this article remains permanently open access under the terms of the Creative Commons Attribution License 4.0 International License

\begin{abstract}
The purpose of this study is to determine the current knowledge, behavior and attitude toward STI prevention among out-of-school youth in the Philippines. Anonymous self-administered questionnaires were distributed separately to 28 out-of-school youth (15 male, 12 female, one unspecified). The mean age of the subjects was $18.0 \pm 3.0$ years, with an overall age range of 15 to 24 years. The female respondents were younger than the male respondents on average. The out-of-school youth obtained information on STIs mainly from the media, and had fewer information sources than in-school students. Although the out-of-school youth had insufficient knowledge of STIs compared to the students, they were fairly knowledgeable about cervical cancer. They were also more sexually active than the students. The out-of-school youth consulted their parents on STI prevention, but received insufficient knowledge on STI prevention from just this source. It was concluded that out-of-school youth could constitute a high risk demographic for STIs, and health education may be essential to help them protect themselves from STIs.
\end{abstract}

Keywords Philippines, Out-of-School Youth, STIs, Prevention Education

\section{Introduction}

HIV/AIDS, a major sexually transmitted infection (STI), is prevalent in the Philippines, with one-third of new HIV infections occurring among young people aged 15-24 years in 2011-2012, a 10-fold increase from 2007-2010 [1-3]. According to the World Health Organization-Western Pacific Regional Office (WHO-WPRO), it is reported that the mean age of sexual debut for Filipinos is about 14-15 years, with $34 \%$ of this age bracket having multiple sexual partners [4]. Unfortunately, awareness of possible STIs is at a low level among young Filipinos. In the Philippines, only $26 \%$ use some form of protection, usually condoms [5]. Thus, young women engage in unprotected sex, putting themselves at risk of contracting STIs $[6,7]$. We demonstrated that many high school students in the Philippines feared STI infection due to insufficient knowledge, and felt anxiety about protecting themselves from STIs [8]. The low level of sexual knowledge and the risky sexual behavior of Filipinos contribute to the increasing prevalence of STIs in the Philippines [9, 10]. Therefore, sexual education may be necessary to prevent STIs among young women in the Philippines.

Meanwhile, according to the 2013 Functional Literacy, Education and Mass Media Survey (FLEMMS) [11], 4 million Filipino children and youth (aged 6 to 14 years, and 15 to 24 years, respectively) did not attend school. Some 22.9 percent of them were in a consensual union or marriage. Among females, four out of 10 were already married, while three out of 10 males had no interest in attending school [12]. These findings indicate that it may be more difficult for out-of-school youth to protect their bodies from STIs through a lack of opportunity to receive STI prevention education compared to students $[12,13]$. Thus out-of-school youth may be at high risk in terms of contracting STIs. However, there are no reports on the current status of STI prevention among out-of-school youth in the Philippines. Thus we conducted the present study to determine the present knowledge, behavior and attitudes toward STI prevention among out-of-school youth in the Philippines, and compared the results with those already reported for a sample of high school students.

\section{Materials and Methods}

\subsection{Materials}

The subjects were out-of-school youth aged 15 to 24 
years, who were not attending school, had not finished school (including elementary school) or any college or post-secondary school course, and were not working. They lived in the same barangays as the high school students who had already been researched. Those who could not read Tagalog or those suffering from mental illnesses were excluded. A health center had a list of out-of-school youth compiled by barangay health workers, and then called for the recruitment of the research participants, with the permission of the out-of-school youth's guardians. The youth were all from low- or middle-income families. The area where they lived was an urban city including a slum district, typical of the Philippines, about 22 kilometers south of Metro Manila, with a population of 505,000 (2015) [14].

\subsection{Method}

\subsubsection{Questionnaire}

An anonymous self-administered questionnaire was distributed to the participants, inquiring about their personal information (sex, age, etc.); information sources and knowledge (knowledge and understanding of prevention) on STIs (STIs in general, HIV/AIDS and cervical cancer); sexual behavior; attitudes toward sexual abstinence; counselors for discussing sexual problems; and opinions. A knowledge test on STIs based on various literature [15-18] covered STIs in general (15 items, scored from 1 to 15 ), HIV/AIDS (11 items, scored from 1 to 11), and HPV infection and cervical cancer (10 items, scored from 1 to 15). The range of possible total scores on the knowledge test was from 6 to 36. The researchers conducted trial tests on out-of-school youth (five male and five female) to determine whether the questionnaire items were appropriate for this demographic. There were no problems in this regard. Attitudes on STI prevention were evaluated using a Sexual Abstinence Behavior Scale comprising four items [19]. We classified the results into six gradations (for example, from $1=$ "strongly disagree" to $6=$ "strongly agree"), and then totaled the scores for the four items, producing a score from 6 to 24. The higher the score for each item, the higher the level of sexual abstinence.

\subsubsection{Multidimensional Health Locus of Control (MHLC)}

The MHLC is one of the scales used to evaluate reinforcements of health-related behavior [20]. It comprises three factors: Internal HLC (IHLC), wherein internal self-regulation is responsible for one's health/illness; Powerful Others HLC (PHLC), wherein one's health/illness is determined by powerful others; and Chance HLC (CHLC), wherein one's health/illness is a matter of fate, luck or chance. These three factors of the MHLC each have six gradations (for each item: 1 = "strongly disagree" and $6=$ "strongly agree"), producing a total score ranging from 6 to 36 . The higher the score for each item, the stronger the reinforcement of health control.

The questionnaires were delivered to the students at their high schools, and to the out-of-school youth in the city hall.

\subsection{Statistical Analysis}

Data analysis was conducted using SPSS Statistics 18.0 for Windows. The descriptive statistics used were the mean, standard deviation, range and percentage. For the out-of-school youth, we used the abbreviation "OSY," and for the high school students, we used the term "Students." Comparisons between the scores of the OSY and the Students were performed using the Man-Whitney U test and the T-test, while analysis of sexual behavior and other items were performed using the Chi-square test. For the MHLC, comparisons among the three factors of the MHLC were performed using One-way ANOVA, while comparisons between the two groups were performed using the Man-Whitney U test.

\subsection{Ethical Considerations}

Participation in the study was voluntary, and the privacy and confidentiality of the participants was strictly protected. In cooperation with the Mayor, the city health office, the health center in A city, we presented this study to two principals, several teachers, all the OSY and their parent(s)/guardian(s), and received their informed consent. This study was approved by the mayor, the city health officer of the Department of Health in A city and the Ethical Committee of Kobe University Graduate School of Health Sciences.

\section{Results}

\subsection{Demographic Characteristics}

Table 1 shows a comparison of the ages of the OSY and the Students. Forty-three OSY were enrolled in this study, yielding 28 valid responses (a response rate of $65.1 \%$ ). There were 15 males, 12 females and one respondent whose sex was unspecified.

Table 1. Comparison of Age among 2 Groups

\begin{tabular}{llllllll}
\hline & \multicolumn{2}{c}{ Out of shool youth } & & \multicolumn{2}{c}{ In students } \\
\cline { 2 - 3 } \cline { 5 - 6 } & $\mathrm{n}$ & Mean \pm SD & & $\mathrm{n}$ & Mean \pm SD & $\mathrm{p}$ \\
\hline Total & $(\mathrm{n}=28)$ & $18.0 \pm 3.0$ & & $(\mathrm{n}=500)$ & $16.2 \pm 1.2$ & $* *$ \\
Male & $(\mathrm{n}=15)$ & $19.5 \pm 2.2$ & & $(\mathrm{n}=245)$ & $16.3 . \pm 1.3$ & $* * *$ \\
Female & $(\mathrm{n}=12)$ & $16.3 \pm 2.7$ & & $(\mathrm{n}=250)$ & $16.1 \pm 1.0$ & $\mathrm{n} . \mathrm{s}$ \\
\hline
\end{tabular}

Mann-Whitney test

$* * \mathrm{p}<0.01, * * * \mathrm{p}<0.001$

The OSY ranged in age from 13 to 24 years, with a mean age of $18.0 \pm 3.0$ years. The mean ages of the male and female OSY were $19.5 \pm 2.2$ years and $16.3 \pm 2.7$ years, 
respectively. There was a significant difference in mean age between the OSY and the Students. The mean age of the female OSY was lower than that of their male counterparts.

\subsection{Knowledge and understanding of STI prevention}

Table 2 shows a comparison of the knowledge and understanding of STI prevention between the two groups (OSY and Students). The rates at which the OSY knew the names of STIs were HIV/AIDS and the HPV vaccine $78.6 \%$, STDs and syphilis $75 \%$, cervical cancer and hepatitis ABC $64.3 \%$, herpes $60.7 \%$, chlamydia trachomatis and gonococcus $53.6 \%$ and HPV $50.0 \%$, respectively. There were significant differences in the rates of knowing the names of STIs, HIV/AIDS, STDs, cervical cancer, hepatitis ABC, herpes, Chlamydia trachomatis, gonococcus and HPV, between the OSY and the Students. Regarding STI prevention in general, the rates at which the OSY understood "Whole STI" were "What are STIs?" 64.3\%, "Asymptomatic infection," 71.4\%, "Fetomaternal infection" 67.9\%, "Excluding genital tract infection" 53.6\%, "Risk factors of life style" 92.9\%, "Sexual activity" 96.4\% and "Check-ups" $85.2 \%$, respectively. There were no significant differences between the two groups except in the case of "Excluding genital tract infection." The rates at which the OSY understood HIV/AIDS prevention were "What is HIV/AIDS?", 88.9\%, "Infection manner" $60.7 \%$, "Fetomaternal infection" 78.6\%, "Sexual activity" $89.3 \%$ and "Prevention" 53.6\%, respectively. Regarding "Fetomaternal infection," "Sexual activity," and "Prevention," the OSY understood significantly less than the Students $(\mathrm{p}<0.05)$. The rates at which the OSY understood about cervical cancer prevention were "What is cervical cancer?" 92.6\%, "Asymptomatic infection" 67.9\%, "Infection manner" and "Prevention" 78.6\% and "Vaccination" and "Check-up" $82.1 \%$, respectively. The OSY understood more than the Students about "What is cervical cancer?" and "Prevention," while the Students understood more than the OSY about "Check-up." There were significant differences between the two groups in these areas. Especially regarding "STIs in general" and "HIV/AIDS," neither the OSY nor the Students understood well about "Asymptomatic infection," "Manner of infection" or "Prevention.". The knowledge scores of the OSY were $10.2 \pm 2.0$ (range 5-14) for "STIs in general, $7.1 \pm 2.4$ (range 2-11) for "HIV/AIDS", $8.2 \pm 1.5$ (range 4-10) for "Cervical cancer", and $25.8 \pm 4.4$ (range 17-34)" for "Total score," respectively. There were no significant differences between the two groups in terms of total scores.

\subsection{Information Sources and the Best Counselors for STIs}

Table 3 shows the information sources and the best counselors for STIs (multiple answers were possible).
Table 2. Comparison of knowledge and understanding prevention STIs among 2 groups

\begin{tabular}{|c|c|c|c|c|c|c|}
\hline & & \multicolumn{2}{|c|}{$\begin{array}{l}\text { Out of school youth } \\
\qquad(\mathrm{n}=28)\end{array}$} & \multicolumn{2}{|c|}{$\begin{array}{c}\text { In students } \\
(\mathrm{n}=500)\end{array}$} & \multirow[b]{2}{*}{$\mathrm{p}$} \\
\hline & & $\mathrm{n}$ & $(\%)$ & $\mathrm{n}$ & (\%) & \\
\hline \multicolumn{7}{|c|}{ Knowledge on STI } \\
\hline 1) & HIV/AIDS & 22 & (78.6) & 485 & $(97.0)$ & $* * *$ \\
\hline 2) & HPV vaccine & 22 & (78.6) & 425 & $(85.0)$ & n.s \\
\hline 3) & STD & 21 & $(75.0)$ & 475 & $(95.0)$ & $* *$ \\
\hline 4) & Syphilis & 21 & $(75.0)$ & 403 & $(80.6)$ & $\mathrm{n} . \mathrm{s}$ \\
\hline 5) & Cervical cancer & 18 & (64.3) & 476 & (95.2) & $* * *$ \\
\hline 6) & Hepatitis ABC & 18 & (64.3) & 475 & $(95.0)$ & $* * *$ \\
\hline 7) & Herpes & 17 & $(60.7)$ & 414 & $(82.8)$ & $* *$ \\
\hline 8) & Chlamydia Trachomatis & 15 & (53.6) & 401 & $(80.2)$ & $* *$ \\
\hline 9) & Gonococcus & 15 & (53.6) & 397 & (79.4) & ** \\
\hline 10) & HPV & 14 & $(50.0)$ & 422 & $(84.4)$ & $* * *$ \\
\hline \multicolumn{7}{|c|}{ Understanding prevention } \\
\hline \multicolumn{7}{|c|}{ Whole STI } \\
\hline 1) & What is STIs? & 18 & $(64.3)$ & 393 & (78.6) & n.s \\
\hline 2) & Asymptomatic infection & 20 & (71.4) & 304 & $(61.0)$ & n.s \\
\hline 3) & Fetomaternal infection & 19 & $(67.9)$ & 249 & $(49.7)$ & n.s \\
\hline 4) & Exclude genital tract infection & 15 & (53.6) & 395 & $(79.0)$ & $*$ \\
\hline$\dagger 5)$ & Risk factors of life style & 26 & $(92.9)$ & 386 & $(77.2)$ & n.s \\
\hline$\dagger 6)$ & Sexual activity & 27 & $(96.4)$ & 467 & $(94.9)$ & n.s \\
\hline$\dagger 7)$ & Check up & 23 & $(85.2)$ & 465 & $(94.5)$ & n.s \\
\hline \multicolumn{7}{|c|}{ HIV/AIDS } \\
\hline$\dagger 1)$ & What is HIV/AIDS? & 24 & $(88.9)$ & 457 & $(91.4)$ & n.s \\
\hline 2) & Infection manner & 17 & $(60.7)$ & 314 & $(62.7)$ & n.s \\
\hline$\dagger 3)$ & Fetomaternal Infection & 22 & (78.6) & 421 & $(84.2)$ & $*$ \\
\hline$\dagger 4)$ & Sexual activity & 25 & $(89.3)$ & 487 & $(97.4)$ & $*$ \\
\hline 5) & Prevention & 15 & (53.6) & 349 & $(69.8)$ & $*$ \\
\hline \multicolumn{7}{|c|}{ Cervical cancer } \\
\hline$\dagger 1)$ & What is Cervical cancer? & 26 & $(92.6)$ & 266 & $(53.2)$ & $* * *$ \\
\hline 2) & Asymptomatic infection & 19 & $(67.9)$ & 330 & $(66.0)$ & $\mathrm{n} . \mathrm{s}$ \\
\hline$\dagger 3)$ & Infection manner & 22 & (78.6) & 360 & $(72.0)$ & $\mathrm{n} . \mathrm{s}$ \\
\hline$\dagger 4)$ & Prevention & 22 & (78.6) & 145 & $(29.0)$ & $* * *$ \\
\hline$\dagger 5)$ & Vaccination & 23 & $(82.1)$ & 345 & $(69.0)$ & $\mathrm{n} . \mathrm{s}$ \\
\hline$\dagger 6)$ & Check up & 23 & $(82.1)$ & 468 & (93.6) & $*$ \\
\hline \multicolumn{2}{|c|}{ Knowledge score } & \multicolumn{2}{|c|}{ Mean \pm SD } & \multicolumn{2}{|c|}{ Mean \pm SD } & \\
\hline & Whole STI (15 items) & \multicolumn{2}{|c|}{$10.5 \pm 2.0$} & \multicolumn{2}{|c|}{$10.5 \pm 2.1$} & n.s \\
\hline & HIV/AIDS (11 items) & \multicolumn{2}{|c|}{$7.1 \pm 2.4$} & \multicolumn{2}{|c|}{$7.9 \pm 1.5$} & n.s \\
\hline & Cervical Cancer (10 items) & \multicolumn{2}{|c|}{$8.2 \pm 1.5$} & \multicolumn{2}{|c|}{$6.4 \pm 1.3$} & $* * *$ \\
\hline & Total (36 items) & \multicolumn{2}{|c|}{$25.8 \pm 4.4$} & \multicolumn{2}{|c|}{$24.9 \pm 2.9$} & n.s \\
\hline
\end{tabular}

Table 3. Information source and the best counselors on STIs

\begin{tabular}{|c|c|c|c|c|}
\hline & \multicolumn{2}{|c|}{$\begin{array}{l}\text { Out of school youth } \\
\qquad(\mathrm{n}=28)\end{array}$} & \multicolumn{2}{|c|}{$\begin{array}{l}\text { In students } \\
(\mathrm{n}=500)\end{array}$} \\
\hline & $\mathrm{n}$ & $(\%)$ & $\mathrm{n}$ & $(\%)$ \\
\hline \multicolumn{5}{|l|}{ Information source } \\
\hline Media & 13 & $(46.3)$ & 376 & $(75.2)$ \\
\hline School & 12 & (42.9) & 390 & (78.0) \\
\hline Internet & 12 & $(42.9)$ & 316 & $(63.2)$ \\
\hline Hospital or Clinic & 12 & $(42.9)$ & 236 & $(47.2)$ \\
\hline Home/Parents & 11 & (39.3) & 218 & $(43.6)$ \\
\hline Same sex friends & 6 & $(21.4)$ & 64 & (12.8) \\
\hline Magazine $\cdot$ Comics & 2 & $(7.1)$ & 132 & $(26.4)$ \\
\hline Others & 1 & (3.6) & 22 & (4.4) \\
\hline Opposite sex friends & 0 & 0.0 & 42 & $(8.4)$ \\
\hline Boyfriend/girlfriend & 0 & 0.0 & 17 & (3.4) \\
\hline \multicolumn{5}{|l|}{ The best counselor } \\
\hline Parents & 17 & $(60.7)$ & 176 & $(74.8)$ \\
\hline Specialist of Health Office or & 12 & $(42.9)$ & 148 & $(59.2)$ \\
\hline Teacher of school & 1 & (3.6) & 80 & (32.0) \\
\hline Friend & 1 & (3.6) & 65 & $(26.0)$ \\
\hline Relative & 1 & (3.6) & 33 & (13.2) \\
\hline Siblings & 2 & (7.1) & 23 & $(9.2)$ \\
\hline Other Specify. & 0 & 0.0 & 11 & $(4.4)$ \\
\hline Neighborhood & 0 & 0.0 & 10 & (4.0) \\
\hline
\end{tabular}


The rate at which the OSY obtained information on STIs from the "media," "school," the "Internet," a "hospital or clinic," "home/parents", "same sex friends" and "magazines or comics" were $46.3 \%, 42.9 \%, 42.9 \%, 42.9 \%, 39.3 \%$, $21.4 \%$, and $7.1 \%$ respectively. Meanwhile, the rates at which the Students obtained information on STIs from the "school," "media," "Internet," a "hospital or clinic," "home/parents," "same sex friends" and "magazines or comics" were 78.0\%, $75.2 \%, 63.2 \%, 47.2 \%, 43.6 \%, 26.4 \%$ and $12.8 \%$, respectively. The OSY were found to have fewer information sources than the Students. The rate at which the OSY selected "Parents," "Specialist at a health office or hospital," "Teachers at school," "Friends," "Relatives" and "Siblings" as the best counselors on STIs were $60.7 \%, 42.9 \%, 3.6 \%$, $3.6 \%, 3.6 \%$ and $7.1 \%$, respectively. The OSY and the Students both selected "Parents" as the best counselors on STIs. Some $26.0 \%$ of the Students selected "Friends", while only $3.6 \%$ of the OSY selected "Friends." The OSY thus had fewer counselors than the Students.

\subsection{Sexual Behavior}

Table 4 shows a comparison of sexual behavior by sex between the OSY and the Students. The rates of affirmative answers to "Have you ever kissed?", "Are you in love (including same-sex love)?", "Do you agree with sex before marriage?" and "Have you ever had sexual intercourse?" were $57.1 \%, 14.3 \%, 40.0 \%$ and $33.3 \%$, respectively, among the male OSY. They were more sexually active than the Students, except in regard to "Are you in love (including same-sex love)?". Meanwhile, the rate of affirmative answers to "Have you ever kissed?", "Are you in love (including same-sex love)?", "Do you agree with sex before marriage?" and "Have you ever had sexual intercourse?" were $75.0 \%, 36.4 \%, 25.0 \%$ and $16.7 \%$, respectively, among the female OSY. The female OSY were more sexually active than the female Students, indicating significant differences between them $(\mathrm{p}<0.001, \mathrm{p}<0.05)$. Meanwhile, the OSY and the Students of both sexes understood that "Having multiple sex partners leads to higher risk of STIs," indicating no significant difference between them for this item. However, in terms of experience of sexual intercourse, males were more sexually active than females among both the OSY and the Students.

Table 4. Comparison of sexual behavior "Yes" for gender among 2 groups

\begin{tabular}{|c|c|c|c|c|c|c|c|c|c|c|c|}
\hline & & \multicolumn{4}{|c|}{ Male } & \multicolumn{5}{|c|}{$\dagger$ Female } & \multirow[b]{3}{*}{$\mathrm{p}$} \\
\hline & & \multicolumn{2}{|c|}{$\begin{array}{l}\text { Out of school youth } \\
\qquad(\mathrm{n}=15)\end{array}$} & \multicolumn{2}{|c|}{$\begin{array}{c}\text { In students } \\
\quad(\mathrm{n}=12)\end{array}$} & \multirow[b]{2}{*}{$\mathrm{p}$} & \multicolumn{2}{|c|}{$\begin{array}{l}\text { Out of school youth } \\
\qquad(\mathrm{n}=12)\end{array}$} & \multicolumn{2}{|c|}{$\begin{array}{l}\text { In students } \\
\qquad(\mathrm{n}=250)\end{array}$} & \\
\hline & & $\mathrm{n}$ & $(\%)$ & $\mathrm{n}$ & $(\%)$ & & $\mathrm{n}$ & $(\%)$ & $\mathrm{n}$ & $(\%)$ & \\
\hline 1) & Do you have a special (boy/girl) friend $\square$ & 9 & $(64.3)$ & 94 & $(37.6)$ & n.s & 9 & $(75.0)$ & 75 & $(30.0)$ & $* *$ \\
\hline 2) & Do you kiss boy/girl friend & 8 & $(57.1)$ & 72 & $(28.8)$ & $*$ & 9 & $(75.0)$ & 41 & (16.4) & $* * *$ \\
\hline$\dagger 3)$ & Are you in love (include homosexual love)? & 2 & (14.3) & 148 & $(59.7)$ & $* *$ & 4 & $(36.4)$ & 174 & $(69.4)$ & $*$ \\
\hline 4) & Do you agree with sex before marriage? & 6 & $(40.0)$ & 34 & (13.7) & $* *$ & 3 & $(25.0)$ & 7 & $(2.8)$ & $* *$ \\
\hline 5) & $\begin{array}{l}\text { Do you want to have sex with your boy/girl } \\
\text { friend }\end{array}$ & 7 & $(50.0)$ & 64 & $(25.6)$ & n.s & 2 & $(16.7)$ & 7 & $(2.8)$ & $*$ \\
\hline 6) & $\begin{array}{l}\text { Did you already have sex with boy/girl friend or } \\
\text { anyone? }\end{array}$ & 5 & $(33.3)$ & 26 & $(10.4)$ & $*$ & 2 & $(16.7)$ & 4 & (1.6) & $*$ \\
\hline$\dagger 7)$ & $\begin{array}{l}\text { If you have sex with many persons or } \\
\text { unknown persons, do you think that you are } \\
\text { high risk for STD? }\end{array}$ & 11 & $(78.6)$ & 187 & $(75.4)$ & n.s & 8 & $(72.7)$ & 189 & $(78.4)$ & n.s \\
\hline
\end{tabular}

Table 5. Comparison of "abstinence" among 2 groups

\begin{tabular}{|c|c|c|c|c|c|c|c|}
\hline & & $\begin{array}{l}\text { Out of school youth } \\
\qquad(\mathrm{n}=24)\end{array}$ & $\begin{array}{c}\text { In students } \\
(\mathrm{n}=489)\end{array}$ & & $\begin{array}{l}\text { Sex experience } \\
(\mathrm{n}=35)\end{array}$ & $\begin{array}{c}\text { Other } \\
(\mathrm{n}=483)\end{array}$ & \\
\hline & & Mean \pm SD & Mean \pm SD & $\mathrm{p}$ & Mean \pm SD & Mean \pm SD & $\mathrm{p}$ \\
\hline 1) & $\begin{array}{l}\text { Tell yourself you were making the right } \\
\text { decision by waiting to have sex }\end{array}$ & $4.5 \pm 1.9$ & $4.9 \pm 1.5$ & n.s & $3.9 \pm 1.9$ & $5.0 \pm 1.4$ & $* * *$ \\
\hline 2) & Say "No" to sex & $4.4 \pm 1.6$ & $4.2 \pm 1.7$ & n.s & $3.0 \pm 1.7$ & $4.3 \pm 1.6$ & $* * *$ \\
\hline 3) & $\begin{array}{l}\text { Tell her (him) that you wanted to wait to have } \\
\text { sex }\end{array}$ & $5.0 \pm 1.5$ & $5.1 \pm 1.3$ & n.s & $4.5 \pm 1.5$ & $5.1 \pm 1.3$ & $* *$ \\
\hline 4) & $\begin{array}{l}\text { Avoid being pressured to have sex by making } \\
\text { sure you are out with a group of people }\end{array}$ & $4.8 \pm 1.4$ & $4.8 \pm 1.4$ & n.s & $4.1 \pm 1.3$ & $4.8 \pm 1.4$ & $* *$ \\
\hline & Total score (4 items) & $17.9 \pm 6.3$ & $19.0 \pm 4.4$ & n.s & $15.5 \pm 4.4$ & $19.2 \pm 4.4$ & $* * *$ \\
\hline
\end{tabular}




\subsection{Sexual Abstinence and MHLC}

Table 5 shows the sexual abstinence scores. The scores for the OSY for "You tell yourself you are making the right decision in waiting to have sex," "You say No to sex," "You tell the other person that you want to wait to have sex," and "You avoid being pressured to have sex by making sure you are out with a group of people," and the total score, were $4.5 \pm 1.9,4.4 \pm 1.6,5.0 \pm 1.5,4.8 \pm 1.4$ and $17.9 \pm 6.3$, respectively. There were differences in the scores for "Sex experience" and "Other" between the two groups. The scores for "Sex experience" were significantly lower than those for "Other" among both the OSY and the Students $(\mathrm{p}<0.001)$.

Table 6 shows a comparison of the total MHLC scores between the two groups. Some $62.8 \%$ of the OSY and $94.0 \%$ of the Students provided valid responses. The scores for the OSY for "Internal," "Chance" and "Powerful Other" were $24.6 \pm 4.2,23.4 \pm 5.7$ and $24.7 \pm 6.3$, respectively. Hence there were no significant differences among the three factors for the OSY. On the other hand, the scores for the Students for "Internal," "Chance" and "Powerful Other" were $24.4 \pm$ $4.7,19.0 \pm 5.2$ and $25.7 \pm 5.4$, respectively, indicating significant differences among the three factors $(\mathrm{p}<0.001)$. Moreover, the score for "Chance" was significantly higher for the OSY than for the Students ( $\mathrm{p}<0.001)$.

Table 6. Comparison of "MHLC" total source among 2 groups

\begin{tabular}{|c|c|c|c|c|}
\hline & $\begin{array}{l}\text { Out of school youth } \\
(\mathrm{n}=27) \\
\end{array}$ & $\begin{array}{c}\text { In students } \\
(\mathrm{n}=470)\end{array}$ & & \\
\hline & Mean \pm SD & Mean \pm SD & & $\mathrm{p}$ \\
\hline Internal & $24.6 \pm 4.27^{\text {n.p }}$ & $24.4 \pm 4.7$ & & n.s \\
\hline Chance & $23.4 \pm 5.7$ & $19.0 \pm 5.2$ & $* * *$ & $* * *$ \\
\hline Powerful Others & $24.7 \pm 6.3^{\lrcorner}$n.p & $25.7 \pm 5.4$ & & n.s \\
\hline
\end{tabular}

One way ANOVA for 3 factors, Mann-Whitney test for 2groups, ${ }^{* * *} \mathrm{p}<0.001$

\section{Discussion}

This is the first time a study had been conducted to demonstrate that out-of-school youth (OSY) in the Philippines had less knowledge and understanding of STI prevention and were more sexually active than students. Furthermore, it was found that fewer information sources and less access to counselors on STI-related topics could contribute to low levels of sexual abstinence and risky sexual health behavior among OSY. The OSY were found to have less knowledge and understanding of STI prevention compared to the Students. As the Students studied about STIs in MAPEH classes at high school, they knew the meanings and consequences of STIs [21]. Several researchers demonstrated that OSY had less knowledge about STI or reproductive health, were at risky situation on STI, and needed sex education classes focused on preventive activities for STI and reproductive health in Nigeria, Uganda and Canada etc [22-26]. Therefore, school-based programs to reduce sexual risk behaviors might be important for OSY $[27,28]$.

The OSY, who regarding counselors for STI-related issues for the OSY, the findings seemed to show a relationship whereby fewer options of counselors other than parents might result in the practice of risky sexual behavior. The OSY's fewer information sources and counselors for STI prevention could be important factors contributing to their lower levels of sexual abstinence [29, 30]. The score for "Chance" in the MHLC was higher among the OSY than among the Students. This indicates that the OSY could not take control of their health, and engaged in risky sexual behavior [31].

The OSY are isolated from school society, because they must work to earn money or take care of child bearing [32, 33]. The WHO report recommends that adolescents need health services for STI prevention based on the country situation [34]. Isuugo-Abanihe et al reported that sex education activities were conducted by Non-Governmental Organizations (NGO), religious organizations, government institutions and other organizations for OSY in Nigeria [35].

What kinds of support are needed to protect OSY from STIs in the Philippines? First, sexual health education (including STI prevention) should be provided to OSY in the community. In particular, female OSY were found to drop out of school more frequently than male OSY due to pregnancy $[36,37]$. Therefore, health centers should play vital roles in the promotion of sexual abstinence and safer sexual activity, including cervical cancer mobile clinics for girls and women in the community [18]. As some OSY cannot read sexual education program brochures written in Tagalog or English, educational materials that communicate to such OSY, such as through graphic illustrations (images such as cartoons) or text in their vernacular on the Internet, may be needed as familiar and easy-to-understand means for OSY to glean information. Therefore, it may be best to promote the provision of sexual health education for OSY through web-based education.

Internet-Based interventions strengthen sexual health knowledge among adolescents [38]. Barak \& fisher reported that Internet-based approach affected health behavior for sexual and reproductive health promotion [39]. Additionally, there were several reports demonstrating Internet-based health promotion in Thailand [40] and Ghana [41].

Secondly, not only should educational programs on STI prevention for OSY cover STIs and preventive behavior, but they should also be provided through an active learning style involving peer education. Peer education particularly includes content that is relevant to OSY's concerns and provides opportunities for them to ask and learn about STI prevention from their own peers. It has been found to be very helpful among teenagers, and can be achieved through events focused on young people in the community $[42,43]$. Health centers and schools need to provide consultation for such young people $[44,45]$. It seems that health centers have important roles to play in STI prevention consultation 
for OSY [46].

Since 2015, the Department of Education has started Alternative Learning System (ALS) in the Philippines [47-49]. This system is to stop dropout school children and youths, and to bring them back to school. It will be expected that web education, peer activity and consultation to prevention STI services for OSY will be offered to through cooperations among of schools, health centers, ALS schools and Education Institution.

\section{Conclusions}

We concluded that the OSY had less knowledge and understanding of STI prevention and were more sexually active than the Students, while fewer information sources and counselors for STIs could be contributing factors to low levels of sexual abstinence and engagement in risky health behavior among the OSY. Therefore, we must provide sexual education (including STI prevention) through web-based education and peer education, and set up a consultation system with nurses on STI-related problems for OSY in the community. Furthermore studies will be necessary to increase the number of OSY, and consider the contents of STI prevention education, peer activities and consultation system according to the target.

\section{Acknowledgements}

We wish to express our appreciation to the research participants (the OSY and their parents); the Mayor of Muntinlupa city; Dr. Magdalena C. Meana of the City Health Officer; the health center staff; and the barangay health workers involved in the present study. To Dr. Rozzano Locsin for his contribution in the development of the manuscript of the study. And we would like to gratefully acknowledge Dr. Kenneth A. Wallston and Prof. Anne E. Norris on the utilization the multidimensional health locus of control scale and the Sexual Abstinence Behavior Scale.

\section{REFERENCES}

[1] Philippines Country Review December 2011, HIV/AIDS DATA HUB FOR ASIA-PACIFIC EVIDENCE TO ACTION, Online available from http://www.aidsdatahub.org/Country-Profiles/Philippines

[2] Facts and Figures 2013, Philippines, Online available fromhttp://aidsdatahub.org/sites/default/files/country_review/ Philippines_fact_sheet_2014.pdf\#search=\%27Prepared+by+ www.aidsdatahub.org+Facts+and+Figures $\% 2 \mathrm{C}+$ Philippin

[3] Department of Health National Epidemiology center (March). Philippines HIV and AIDS Registry, 2013. Online available from

http://www.doh.gov.ph/.../NEC_HIV_December-AIDSreg20 13.pdf
[4] Sexual and Reproductive Health of Adolescents and Youths in the Philippines: a review of related literature and projects 1995-2003. World Health Organization-Western Pacific Regional office (WHO-WPRO); 2005. Online available from http://www.wpro.who.int/publications/docs/ASRHphilippines .pdf

[5] Risk of HIV/AIDS due to Unprotected Sex, ADOLESCENT AND YOUTH HEALTH PROGRAM (AYHP), Philippines. Online available from

http://www.doh.gov.ph/adolescent-and-youth-health-program

[6] Philippines National Demographic and Health Survey 2013 [FR294]. Online available from dhsprogram.com/pubs/pdf/FR294/FR294.pdf

[7] Ushma D.Upadhyay, Michelle J.Hindin and Socorro Gultiano, Before First Sex: Gender Differences in Emotional Relationships and Physical Behaviors Among Adolescents In the Philippines, International Perspectives on Sexual and Reproductive Health, Vol.32, Issue 3:110-119, 2006.

[8] Yuko Tanaka, Cecilia L. Llave, Tadashi Yamashita, Hiroya Matsuo, The Current situation of knowledge, behavior and attitude related to STIs prevention among high school students in the Philippines, Bulletin of health sciences Kobe, Vol.31,1-13, 2015.

[9] Amala Reddy, Khin Cho Win Htin, Ye Yu Shwe, HIV and AIDS Data Hub for Asia Pacific: a regional tool to support strategic information needs; Country progress report Philippines. Western Pacific Surveillance and Response Journal, Vol.3, No.3, 18-21, 2012.

[10] Unintended Pregnancy and Unsafe Abortion in The Philippines: Context and Consequences, 2013 Series, No3, Guttmacher Institute. Online available from https://www.guttmacher.org/report/unintended-pregnancy-an d-unsafe-abortion-philippines-context-and-consequences

[11] Out-of-School Children and Youth in the Philippines, PHILIPPINEP STATISTICS AUTHORITY, Republic of the Philippines (Results from the 2013. Functional Literacy, Education and Mass Media Survey) Reference Number: 2015-029, Release Date: Monday, April 20, 2015. Online available from

https://psa.gov.ph/content/out-school-children-and-youth-phil ippines-results-2013-functional-literacy-education-and.

[12] A glimpse at the school dropout problem, The Filipino child, Policy Brief No.4, Unicef, 2010. Online available from http://dirp4.pids.gov.ph/ris/pn/pidsbrief04.pdf

[13] Florence N Samkange-Zeeb, Lena Spallek, Hajo Zeeb, Awareness and knowledge of sexually transmitted disease (STDs) among school -going adolescents in Europe: a systematic review of published literature, BMC Public Health, 2011.

[14] About the city, Muntinlupa City's Official Website: Available from:

http://www.muntinlupacity.gov.ph/index.php?target=about\& params=request_._resord\#. Accessed 20 May 2015.

[15] Jamie Z. Galvez Tan, Evelina M. Vicencio, Raymundo S. Baquiran, et al. The Health Curriculum in Philippines Basic Education 2, UNACOM, Social and Human Sciences Committee, 2009. 
[16] Sex education enters school curriculum, Department of Education, Philippines AIDS Council-Department of Education (DepEd). Online available from http://www.pnac.org.ph/index.php?mact=News, cntnt01, detail, 0 \& cntnt01. [Muntinlupa City's Official Website. On line available from

http://www.muntinlupacity.gov.ph/index.php?target=about\& params=request_._resord\#

[17] MA. Alodia C. Frontanilla. Instructional Modules on Sex Education for College Students. Rex Book Store, Philippines, 2003

[18] Cecilia Ladines-Llave. The Burden of Cervical Cancer in the Philippines and Efforts to Combat the Disease, This paper was presented at the John Hopkins-JHPIEGO Global Conference on Low-Resource Setting Cervical Cancer Prevention. held in Bangkok, Thailand on Dec. 4, 2005. Online available fromhttp://www.ellentordesillas.com/2006/08/12/the-burdenof-cervical-cancer-in-the-philippines-and-efforts-to-combat- $t$ he-disease/\#sthash.kebiscox.dpuf.

[19] Anne E. Norris, Leslie F. Clark, Sondra Magnus, Sexual abstinence and the Sexual Abstinence Behavior Scale, Journal of Pediatric Health Care, Vol.17, Issue 3, 140-144, 2003.

[20] Wallston KA, Wallston BS, DeVellis R. Development of the Multidimensional health locus of control (MHLC) scales. Journal of Health Education Monographs Vol.6, 160-170, 1978.

[21] DM 193, s. 2010 - Training Of First Year Teachers Of Technology And Livelihood Education (Tle), Music And Arts, Physical Education And Health (Mapeh) And Edukasyon Sa Pagpapahalaga (Ep) On The 2010 Secondary Education Curriculum (Sec). Department of education in the Philippines, April 29, 2010. Online available from available from: http://www.deped.gov.ph/sites/default/files/memo/2010/DM_ s2010_193.pdf.

[22] UNFPA Operational Guidance for Comprehensive Sexuality Education: A Focus on Human Rights and Gender A Focus on Human Rights and Gender, United Nations Population Fund (UNFPA), 2014. Online available from http://www.unfpa.org/sites/default/files/pub-pdf/UNFPA\%20 Operational\%20Guidance\%20for\%20CSE\%20-

Final\%20WEB\%20Version.pdf

[23] Prosper Adogu, Ifeoma Udigwe, Achunam Nwabueze, Echendu Adinma, Gerald Udigwe, Chika Onwasigwe, Sexual health knowledge, attitude and risk perception among in-school and out-of-school female adolescents in Onitsha, Anambra State, Nigeria, South Eastern European Journal of Public Health (SEEJPH), 1-11, 2014.

[24] Uche C. Isiugo-Abanihe, Rasak Olajide, Ezebunwa Nwokocha, Funke Fayehun, Rasheed Okunola and Retta Akingbade, Adolescent sexuality and life skills education in Nigeria: To What Extent have Out-of-school Adolescents Been Reached?, African Journal of Reproductive Health, Vol.19, No.1,101-111, 2015.

[25] ABUBAKAR ISA SULEIMAN, Sexual behaviour and knowledge of sexually transmitted infections including hiv/aids among in school and out of school adolescents kumbotso local government area, kano state, 2011. On line available from http://www.academia.edu/2305218/SEXUAL_BEHAVIOUR AND_KNOWLEDGE_OF_SEXUALLY_TRANSMITTED_ INFECTIONS_INCLUDING_HIV_AIDS_AMONG_IN_SC HOOL_AND_OUT_OF_SCHOOL_
[26] Bannet Ndyanabangi, Walter Kipp, and Hans-Jochen Diesfeld, Reproductive Health Behaviour among In-School and Out-of-School Youth in Kabarole District, Uganda, African Journal of Reproductive Health, Vol.8, No.3, 55-67, 2004.

[27] Souradet Y. Shaw, Colleen Metge, Carole Taylor et al, Teen clinics: missing the mark? Comparing pregnancy and sexually transmitted infections rates among enrolled and non-enrolled adolescents, International Journal for Equity in Health, 15:95, 2016.

[28] Kirby D, Short L, Collins J, Rugg D, Kolbe L, Howard M, Miller B, Sonenstein F, Zabin LS. School-based programs to reduce sexual risk behaviors: a review of effectiveness, Public Health Rep, Vol.109, 339-60, 1994.

[29] Berja, Clarinda L., Case study, Philippines: communication and advocacy strategies adolescent reproductive and sexual health. Bangkok: United Nations Population Fund (UNFPA), 1999. Online available from http://unesdoc.unesco.org/images/0012/001200/120036E.pdf

[30] Romel Saulong Lacson, Theocharis R. Theocharis, Robert Strack, et all, Correlates of Sexual Abstinence Among Urban University Students in the Philippines, International Family Planning Perspectives, Vol.23, No.4, December 1997.

[31] Jimoh SHEHU \& Martin M. MOKGWATHI, HEALTH LOCUS OF CONTROL AND INTERNAL RESILIENCE FACTORS AMONG ADOLESCENTS IN BOTSWANA: A CASE-CONTROL STUDY WITH IMPLICATIONS FOR PHYSICAL EDUCATION, South African Journal for Research in Sport, Physical Education and Recreation, Vol.30, No.2, 95-105, 2008.

[32] Percentage of children aged 5-14 years engaged in child labour (by sex, place of residence and household wealth quintile), Unicef, 2016

[33] Nick M. Arcilla, The Filipino Children in Prostitution- A Worst Form of Child Labour-, Migrante-Anak-Pamilya (MAP) Foundation, Inc, International Labour Organisation (ILO) International Programme on the Elimination of Child Labour (IPEC) Manila, Philippines December 2001.

[34] Karl L Dehne, Gabriele Riedner, Sexually Transmitted Infections among Adolescents: The Need for adequate Health Services, Department of Child and Adolescent Health and Development (CAH) World Health Organization, 2005. Online available fromhttp://apps.who.int/iris/bitstream/10665/43221/1/924156 2889.pdf\#search=\%27Outofschool+STI+asia\%27

[35] Carroll C, Lloyd-Jones M, Cooke J, Owen J. Reasons for the use and non-use of school sexual health services: a systematic review of young people's views. J Public Health (Oxf), Vol. 34, 403-10, 2012

[36] Manlove J. The influence of high school dropout and school disengagement on the risk of school-age pregnancy. J Res Adolescent, Vol.8, 187-220, 1998.

[37] Nickel NC, Chateau DG, Martens PJ, Brownell MD, Katz A, Burland EM, Walld R, Hu M, Taylor CR, Sarkar J, et al. Teen clinics: missing the mark? Comparing pregnancy and sexually transmitted infections rates among enrolled and non-enrolled adolescents, International Journal for Equity in Health. 2016; 15: 95 . 
[38] Laura Simon, Kristian Daneback, ADOLESCENTS' USE OF THE INTERNET FOR SEX EDUCATION: A THEMATIC AND CRITICAL REVIEW OF THE LITERATURE, International Journal of Sexual Health, Vol.25, 305-319, 2013.

[39] AZY BARAK \& WILLIAM A. FISHER, Experience with an Internet-based, theoretically grounded educational resource for the promotion of sexual and reproductive health, Sexual and Relationship Therapy Vol.18, No.3, August 2003.

[40] Thanomwong Poorisat \& Arul Chib, Internet as a sex education tool: A case study of an online Thai discussion board, Chapter 14, On line available from file:///Users/yuko/Downloads/Thanomwong\&Chib_2014\%20 (1).pdf

[41] Dina L. G. Borzekowski Julius N. Fobil and Kofi O. Asante Johns Hopkins Bloomberg School of Public Health University of Ghana Ghanaian Teens' Use of the Internet for Health Information, Developmental Psychology ,the American Psychological Association, Vol.42, No.3, 450-458, 2006.

[42] Peer education and HIV/AIDS: Concepts, uses and challenges, UNAIDS, 1999. Online available fromhttp://www.unaids.org/sites/default/files/media_asset/jc2 91-peereduc_en_0.pdf.

[43] Denise Jaworsky, June Larkin, Gobika Sriranganathan, et al, Evaluating Youth Sexual Health Peer Education Programs: Challenges and Suggestions for Effective Evaluation Practices, Journal of Education and Training Studies Vol.1, No.1, April 2013.
[44] Cary J. Roseth, David W. Johnson, and Roger T., Promoting Early Adolescents' Achievement and Peer Relationships: The Effects of Cooperative, Competitive, and Individualistic Goal Structures, Psychological Bulletin Copyright 2008 by the American Psychological Association, Vol.134, No.2, 223-246, 2008.

[45] Jose A. Bauermeister, Katherine Elkington, Elizabeth BrackisCott, et al, Sexual behavior and perceived peer norms: Comparing perinatally infected and affected youth, Journal Youth Adolescent, Vol.38, No.88, 1110-1122, 2009.

[46] Kerns SE, Pullmann MD, Walker SC, Lyon AR, Cosgrove TJ, Bruns EJ. Adolescent use of school-based health centers and high school dropout, Arch Pediatric Adolescent Med, Vol.165, 617-623, 2011.

[47] Leaving no one behind: How far on the way to universal primary and secondary education? POLICY PAPER 27/ FACT SHEET 37 July 2016. On line available from http://uis.unesco.org/en/news/263-million-children-andyouth-are-out-school

[48] A growing number of children and adolescents are out of school as aid fails to meet the mark Global Initiative on Out-of-School Children, 2015, On line available from http://www.uis.unesco.org/Education/Documents/fs-31-out-o f-school-children-en.pdf.

[49] Carolina Guererro, Education for All Global Monitoring Report 2008 Education for All by 2015: will we make it? Philippines Non-formal education, United Nations Educational, Scientific and Cultural Organization (UNESCO), 2008. Online available from http://unesdoc.unesco.org/images/0015/001555/155532e.pdf\# search $=\% 27$ ALS+UNSCO+Philippines $\% 27$ 